\title{
Callus induction and growth of tissue cultures derived from cucumber plant organs of four different sex types
}

\author{
W. MACIEJEWSKA-POTAPCZYKOWA, A. RENNERT, E. MILEWSKA \\ Department of Plant Physiology, Institute of Biochemistry \\ and Physiology, University of Lodz, \\ Nowopołudniowa 12, Łódź, Poland \\ (Received: June 8, 1971.)
}

\begin{abstract}
In order to determine the concentration ranges of IAA and kinetin required for callus induction and subsequent callus growth, stem pieces and floral buds from plants of four various sex types of Cucumis sativus $\mathrm{L}$. were grown in the in vitro culture. Requirements for phytohormones depend upon the kind of organ and the sex line. Tissues of male and monoecious lines were more sensitive to IAA deficiency, whereas male and hermaphrodite ones to kinetin deficiency. This tendency has been observed to occur for nearly 18 months.
\end{abstract}

\section{INTRODUCTION}

In the culture of isolated plant tissues a totipotency of the plant cell is distinctly noticeable. It is based on the possibilities of various expression of genetic information under definite conditions. In connection with that, the genetic problems of cell populations cultured on known media and subjected to the action of definite factors are of great importance.

This research deals with tracing callus tissue's origin from the fragments of plants of four various sex types of Cucumis sativus $\mathrm{L}$. Cucumber belongs to monoecious plants but in this species there exist genetic lines of monoecious, gynoecious (purely female), male and hermaphrodite plants. Some investigations concerning the mechanism of sex differentiation in cucumber indicate that both genetic factors and the environmental conditions influence sex determination by changes in the hormone level in the neighbourhood of the developing floral bud (Astmon and Galun 1962; Galun 1959; Galun et al. 1965; Kubicki 1965).

A continous of callus tissues, obtained from the stem fragments situated below the floral buds and from floral buds of the above mentioned cucumber plants could be a convenient material for a biochemical study on the mechanism of sex determination at the cell level. No information concerning conditions suitable for the growth in vitro of cucumber callus tissue has been found in literature. 


\section{MATERIAL AND METHODS}

Plant material. The following varieties of Cucumis sativus L. derived from pure genetic lines were used:

1. Monoecious Mo-298 obtained by way of self-pollination and selection from 'Monastyrski' variety, producing male and female flowers.

2. Male An-314 being a mutation of the chinese variety 'E-e-Szań'.

3. Hermaphrodite H-713-5 obtained from the female variety MSU-713-5 by introducing the gene $\mathrm{m}$ causing the formation of hermaphrodite flowers.

4. Female G-MSU-713-5 brought from USA and reproduced in Skierniewice over several generations.

Plants were grown under standard conditions from seeds obtained from the Genetics Department of the Polish Academy of Sciences in Skierniewice. Plants were harvested 20 days after planting. Fragments $(1 \mathrm{~cm})$ of the apical stem part and about $0.5 \mathrm{~cm}$ floral buds were cut off. The material was sterilized in $0.1 \% \mathrm{HgCl}_{2}$ for 10 minutes and rinsed several times with sterile water. Then the plant parts were placed on agar medium.

In vitro cultures were grown in an incubator at temperature $25^{\circ}$ under continuous fluorescent light.

Culture medium. The composition of the standard culture medium was developed empirically starting with Murashige and Skoog medium (1962) with addition of thiamin (Linsmaier and Skoog 1965) and bee bread extract in $2 \mathrm{~g} / 1$ concentration (Rennert 1968) that proved to be of advantage. Taking into consideration the genetic differences in the material under examination we changed IAA and kinetin concentrations in the respective experiments. $\mathrm{pH}$ was adjusted to 5.6; sterilization was performed in an autoclave at $120^{\circ}$ for 15 minutes.

Preliminary experiments made in order to estimate the usefulness of the respective media for the culture in vitro of cucumber tissues were performed only with monoecious plants. Since these tests were not made systematically with all possible combinations, the medium should not be considered as optimal. This medium, however, favours callus formation both on: stem fragments and floral buds from plants of the genetic lines under examination.

\section{EXPERIMENTS}

Floral buds. Floral buds dissected out from plants of the respective sex types were placed on the media containing various IAA concentrations and kinetin as seen in Table 1. After 4 weeks of culture a part of buds was lost. We did not observe any growth of callus, but numerous buds maintained their good appearance and a part of them (hermaphrodite and female buds) showed a slight growth. In order to stimulate callus formation in buds, living and healthy buds of passage I were transferred - as a whole or halved - on subsequent media containing another IAA and kinetin in different concentrations (Table 2). 
Stem fragments. The stem explants were transfered on the medium in which the IAA concentration was $2 \mathrm{mg} / \mathrm{l}$ and that of kinetin $2.2 \mathrm{mg} / \mathrm{l}$. In this medium a part of the fragments of all series developed organs; others however, formed callus tissue on the entire surface of maternal fragment. These calluses were dissected off and reproduced by transfering on a fresh medium of the same composition (passage II). The material obtained after 5 weeks culture was used in the experiments made in order to establish the optimum concentrations of IAA and kinetin for the growth of callus as related to the sex type of the original plant. The results of these experiments are summarized in table $3 \mathrm{~A}$ (passage III). The second analogous experiment was performed in passage $\mathrm{V}$ (Table 3B).

\section{RESULTS}

Floral buds. The choice of an appropriate medium for the culture of cucumber plant fragments was made with the intention to stimulate the growth of callus but not further bud development. However the observation of bud behaviour on this medium allowed some conclusions. The results summarized in Table 1 show that

\section{Table 1}

Influence of various IAA and kinetin concentrations of floral buds isolated from cucumber plants of four genetic lines cultured in vitro (passage I)

\begin{tabular}{|c|c|c|c|c|c|}
\hline \multicolumn{2}{|l|}{ LINES } & Mo-298 & An-314 & H-713-5 & G-713-5 \\
\hline \multirow{2}{*}{$\begin{array}{l}\text { Concentrations } \\
\text { in } \mathrm{mg} / \mathrm{l} \text { of medium }\end{array}$} & IAA & $2.02 .0-$ & $2.02 .0-$ & $2.02 .0-$ & $2.02 .0-$ \\
\hline & kinetin & $0.2 \quad 2.2 \quad 2.2$ & $0.2 \quad 2.2 \quad 2.2$ & $0.2 \quad 2.2 \quad 2.2$ & $\begin{array}{lll}0.2 & 2.2 & 2.2\end{array}$ \\
\hline \multicolumn{2}{|l|}{ Initial bud number } & 9279 & 9279 & 9259 & 7147 \\
\hline \multicolumn{2}{|l|}{$\begin{array}{l}\text { Number of living buds } \\
\text { after } 4 \text { weeks culture }\end{array}$} & $-20-$ & $-20-$ & $320+3$ & $612+5$ \\
\hline
\end{tabular}

- dead buds; + buds showing an increase in volume.

at concentrations $2 \mathrm{mg} / 1 \mathrm{IAA}$ and $2.2 \mathrm{mg} / \mathrm{l}$ of kinetin, the buds of all genetic lines remained alive and seemed healthy; a slight growth was observed only in bud of hermaphrodite and female lines. The buds of male and monoecious lines, however, died if auxin was lacking in the medium and also at $2 \mathrm{mg} / 1$ of IAA and $0.2 \mathrm{mg} / 1$ of kinetin. The buds of the remainining lines did not show any sensitivity to the lack of auxin.

Callus formation on buds was observed in subsequent passage (Table 2). Callus tissues appeared in the neighbourhood of the floral bottom; this phenomenon was independent of whether an integer bud was present on the medium or its half only (Phot. 1). Induction of callus formation on the buds of all lines was most intensive at a high IAA level $(5 \mathrm{mg} / \mathrm{l})$ and the presence of $1 \mathrm{mg} / 1$ kinetin. Similarly as in the previous passage, on the media deprived of IAA the buds of male and monoecious 


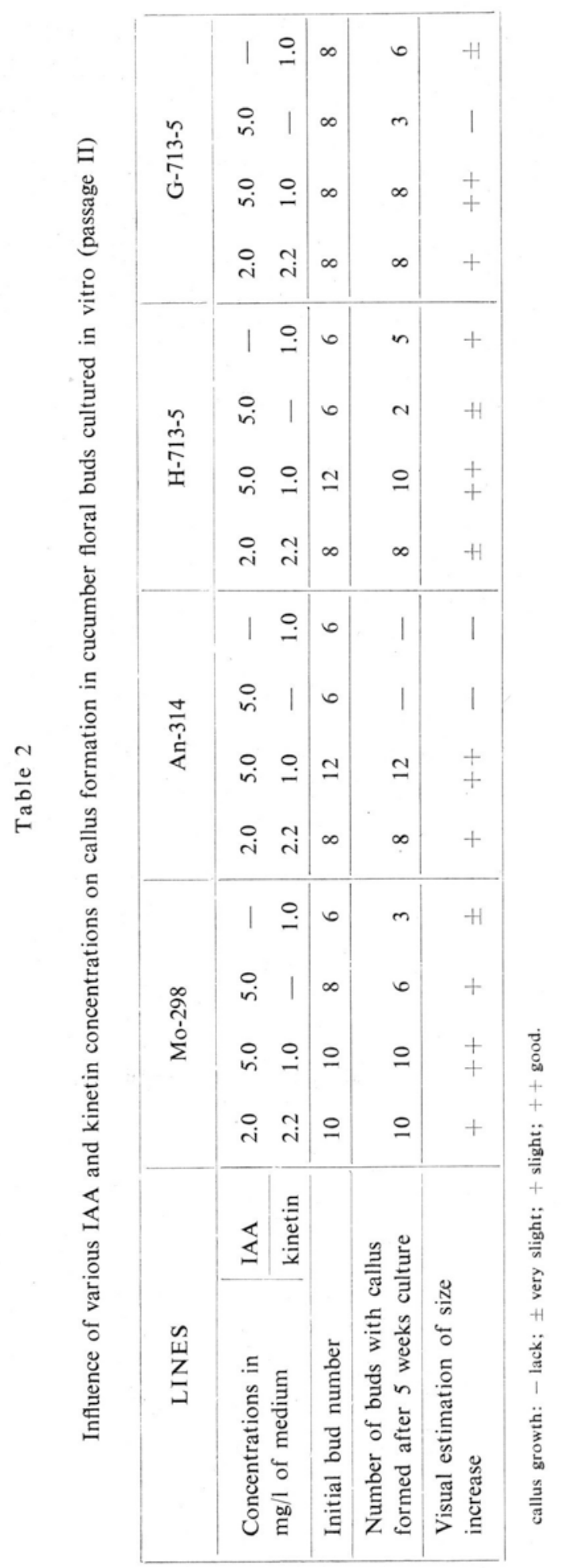




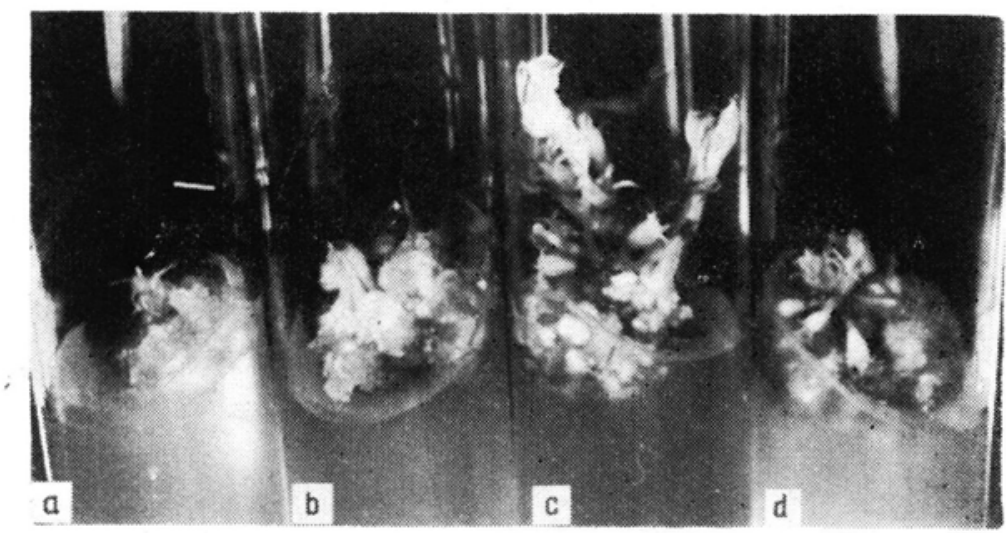

Photo 1. Morphogenesis of cucumber explants cultured in vitro

$a, b$ - callus formed in the neighbourhood of the floral bottom of isolated bud; $c, d$ - flowers on shortened stalks growing out of isolated stem fragments
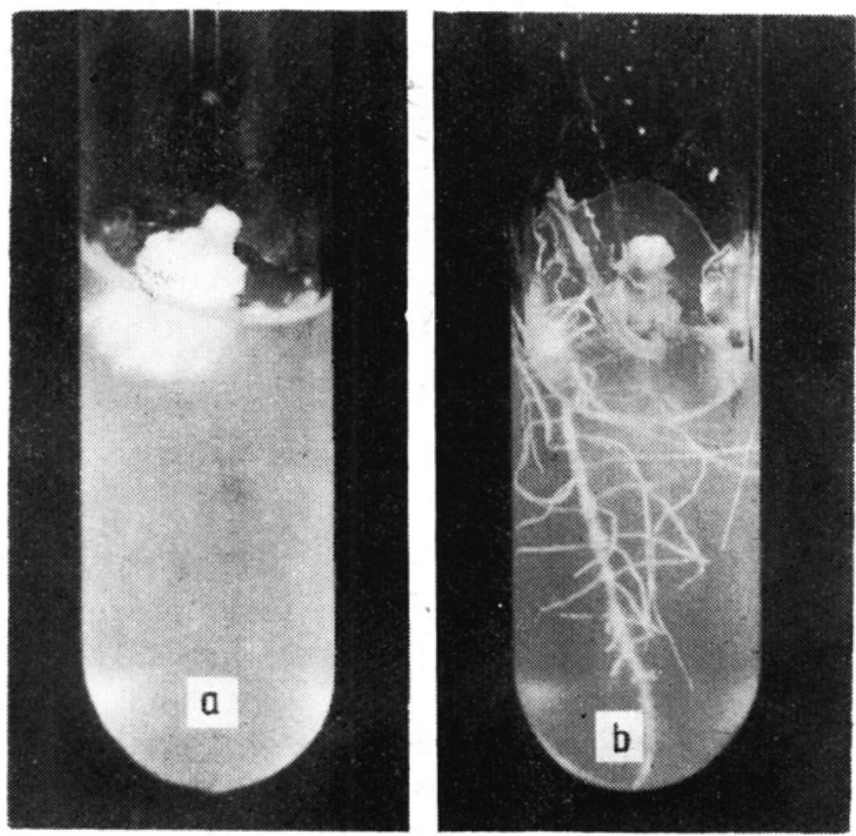

Photo 2. Growth of stem fragments isolated from cucumber

$a$ - callus formed around maternal tissue: $b$ - root and leaves growing out of stem fragment

lines died and the callus formation in the remaining groups was very slight. IAA alone did not stimulate growth of callus tissue.

Stem fragments. The media applied in the experiments ensure the conditions necessary for callus formation on cucumber stem segments. Apart from this they 


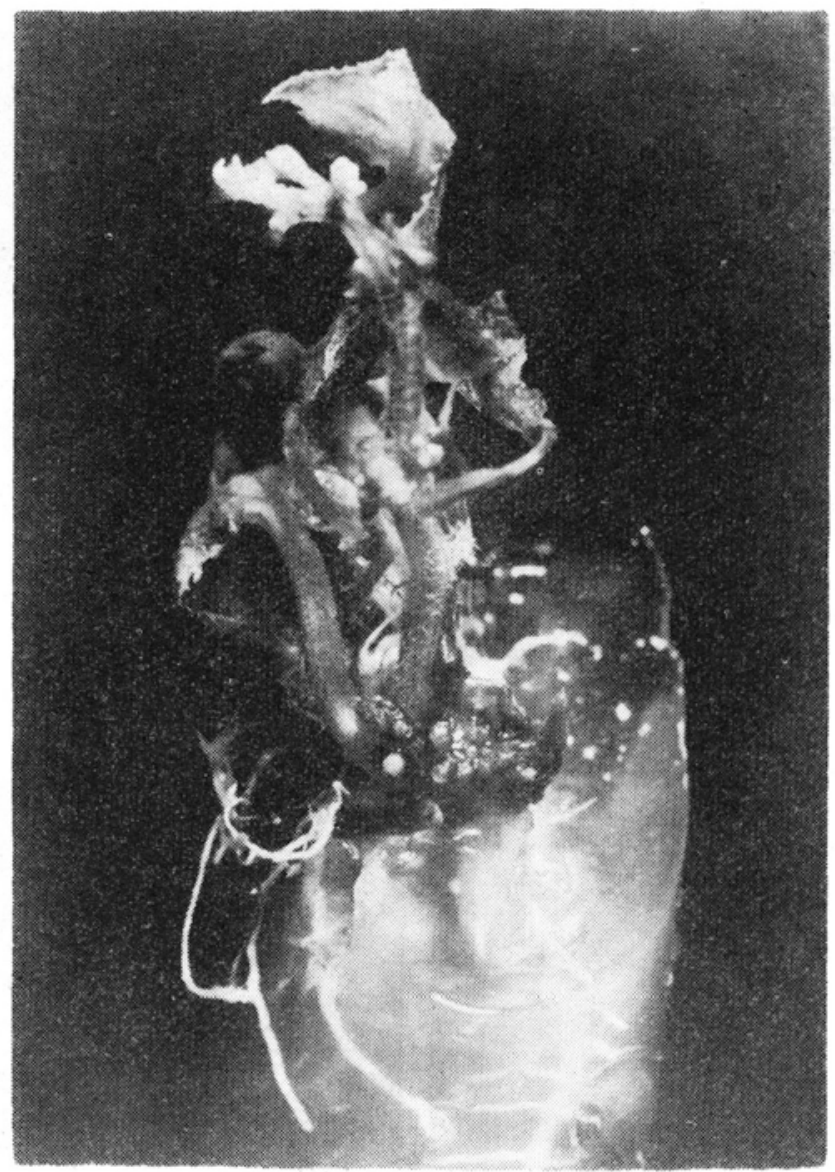

Photo 3. Cucumber plant grown in vitro, with all organs formed

are favourable for revealing the ability of these tissues for the organ formation. A part of the fragments of all sex types formed the organs. The formation of well developed roots, leaves (Photos 2,3) and whole plants with floral buds and flowers on shortened stalks was observed. An abundance of flowers was characteristic for material derived from monoecious plants (Photo 1). The calluses separated from their maternal tissues maintained in subsequent passages their ability of root formation at high concentration of IAA in the medium $5 \mathrm{mg} / 1$ and $1 \mathrm{mg} / \mathrm{l}$ of kinetin. At higher concentrations of kinetin the groups of dark-green cells forming bud primordia protruding over a colony surface appeared on light calluses derived from the stems of male plants.

As the growth of callus tissues proceeding, at first with good effect on the starting medium containing $2 \mathrm{mg} / \mathrm{l}$ of IAA and $2.2 \mathrm{mg} / \mathrm{l}$ of kinetin, was inhibited in subsequent passages. The concentration of these substances were changed several times. The transfer of calluses to a medium containing $5 \mathrm{mg} / \mathrm{l}$ of IAA and $1 \mathrm{mg} / \mathrm{l}$ 


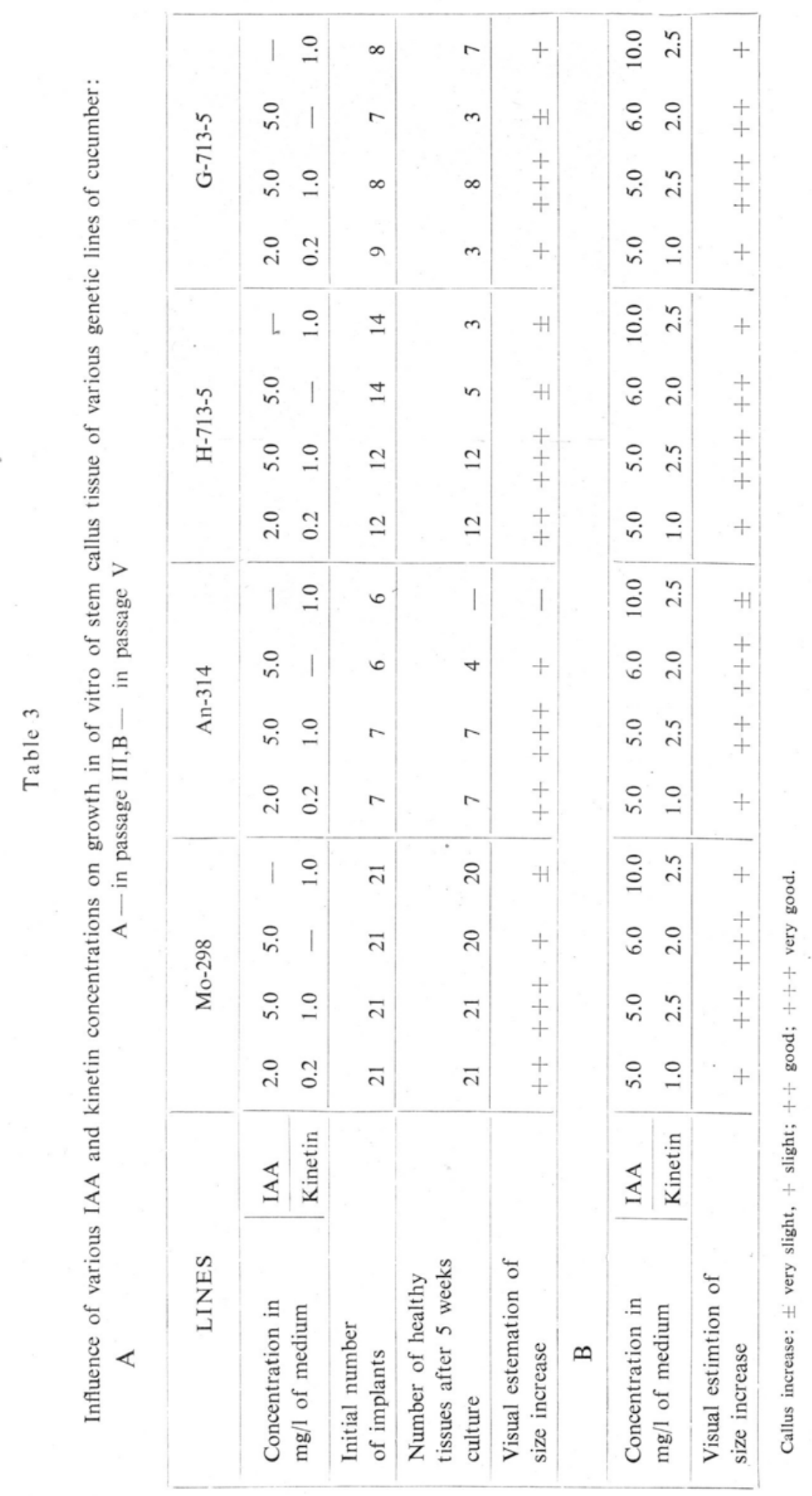




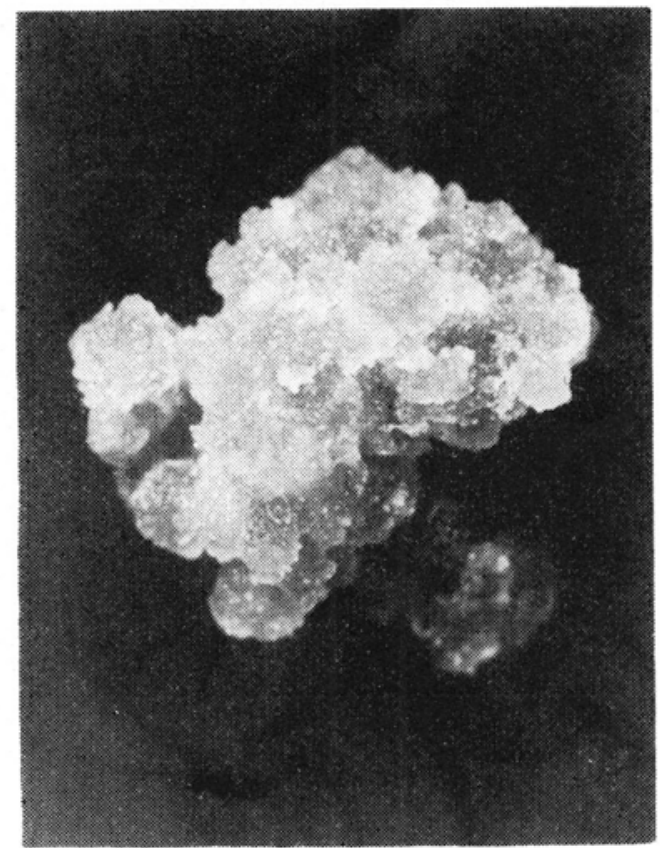

Photo 4. Callus tissue of cucumber stem after 10 months of culture

of kinetin in passage III induced growth stimulation of all lines of tissues, however when IAA was lacking in the medium the growth of all tissues was stopped, particularly in the case of the male line. The tissues of female and hermaphrodite lines proved to be the most sensitive to kinetin deficiency. The results of experiments in passage III are summarized in tatle 3A. A dependence of callus tissue growth on IAA and kinetin concentrations in subsequent passages is shown in table 3B. It was found that concentrations of the regulators under examination that is 5 $\mathrm{mg} / \mathrm{l}$ of IAA and $1 \mathrm{mg} / \mathrm{l}$ of kinetin become insufficient for maintaining the growth of these tissues in passage V. In the case of tissues of monoecious and male lines an optimal ratio of IAA to kinetin is $3: 1$ (6 mg/l of IAA and $2 \mathrm{mg} / \mathrm{l}$ of kinetin); in hermaphrodite and female lines, however, this ratio is $2: 1(5 \mathrm{mg} / 1 \mathrm{of}$ IAA and $2.5 \mathrm{mg} / \mathrm{l}$ of kinetin). Higher concentraticn of IAA $(10 \mathrm{mg} / \mathrm{l})$ inhibits the growth of calluses in all groups. The optimal IAA and kinetin concentrations found for tissues in passage $\mathrm{V}$ were sufficient to maintain their good growth in continuous culture (Photo 4).

\section{DISCUSSION}

The extensive literature giving detailed information of the nutritional requirements of various plant tissues cultured in vitro contains only very few data on the medium composition and culture conditions necessary for the growth of isolated 
cucumber fragments. The medium applied by Galun et al. (1963) suitable for the growth and development of isolated floral buds contains exclusively nitrates as inorganic nitrogen source and the amounts of nitrogen, potassium and phosphorus used after White seen to be too low. Tracing of the origin of the cucumber tissue culture presents difficulties also because of the lack of data dealing with the quantitative proportions of the respective growth regulators. Therefore in the present investigations it was endeavoured to establish the IAA and kinetin concentrations required for the formation and growth in vitro of callus tissues on the fragments of plants under examination. We used with success the relatively universal medium of Murashiege and Skoog (1962) supplemented with bee bread extract (Rennert, Gubański 1962) instead of coconut milk used by Galun et al. (1962, 1963). Bee bread extract had a positive effect on the growth of cucumber tissues. It results from our previous investigations that bee bread, apart from nonspecific growth stimulation of tissues cultured in vitro, shows also an activity similar to that of kinetin. The extract containing $4 \mathrm{~g}$ of bee bread in 1 litre of medium stimulates the growth of callus tissue from Nicotiana tabacum var 'Wisconsin' 38 pith to the same extent as does $0.03 \mathrm{mg} / \mathrm{l}$ kinetin (Rennert 1968, unpublished data).

In order to obtain callus cultures from material representing various sex types we isolated sub-buds stem fragments and floral buds from the corresponding cucumber plants. It was found that their requirements as related to IAA and kinetin are dependent both on the kind of tissue and the sex type of the plant. Taking into consideration some data in the literature concerning the influence of phytohormones on sex differentiation, this seems quite obvious (Galun et al. 1965; Preira 1968).

On the medium applied in our experiments we observed neither growth nor development of organized structures in buds. Nevertheless it should be emphasised that this medium contained neither vitamins nor any other components used by Galun et al. (1963). The lack of IAA or kinetin in the medium caused a complete or partial death of the buds of the respective lines. The buds of male and monoecious lines showed a particular sensitivity to the lack of IAA as compared to those of remaining lines. Probably the buds of hermaphrodite and female lines contain a greater stock of endogenous auxin (see Galun et al. 1965). Callus formation in the buds of all series was obtained by increasing IAA concentration to $5 \mathrm{mg} / \mathrm{l}$ with kinetin $(1 \mathrm{mg} / \mathrm{l})$ simultaneously added. The formation of callus tissues on the stem segments from plants of all genetic cucumber lines was very intensive. The concentrations of IAA and kinetin stimulating the growth of these tissues changed in the course of several succesive passages. This simultaneous requirement of two growth substances in the first period of tissue culture could be explained by the fact, that they still contain at this time a certain stock of endogenous growth regulators. Therefore the differences in the sensivity to IAA and kinetin concentrations observed between tissues of the respective genetic lines give information of the relations existing between endogenous growth regulators and the sex type. The results of our experiments indicate that tissues of female and hermaphrodite lines are more sensitive to kinetin deficiency as compared to those of monoecious and 
male lines. The latter ones however are more sensitive to the lack of IAA. It should be noticed that this tendency subsists for a long time of the culture lasting and by the same also when adaptation to entirely new growth conditions took place.

\section{SUMMARY AND CONCLUSIONS}

Apical stem fragments and flower buds from various sex types of Cucumis sativus L. were cultured under sterile conditions on the Linsmaier and Skoog medium supplemented with bee bread extracts, $2 \mathrm{mg} / 1$ of IAA and $2.2 \mathrm{mg} / \mathrm{l}$ of kinetin. The calluses formed on stem segments and on integer or halved flower buds were transferred to the fresh media containing various combinations of IAA and kinetin.

When auxin is absent from the medium as well as at its low concentration $(2 \mathrm{mg} / \mathrm{l})$ the flower, buds of male and monoecious lines died, those however of female and hermaphrodite lines showed a slight growth without callus formation. Callus induction was observed in the buds of all lines at high IAA level $(6 \mathrm{mg} / \mathrm{l})$ and in the presence of kinetin $(1 \mathrm{mg} / \mathrm{l})$. IAA alone did not stimulate any growth of callus.

The growth of callus tissues on the stem fragments required both regulators. Their optimal concentrations fluctuated during several initial passages depending on the sex type. The optimal concentrations of IAA and kinetin (within the range of concentrations used in our experiments) were found in the 5-th passage: for monoecious and male lines to be 6 and $2 \mathrm{mg} / \mathrm{l}$, for hermaphrodite and female lines 5 and $2.5 \mathrm{mg} / 1$, respectively.

Our experiments showed that the tissues of male and monoecious lines are more sensitive to IAA deficiency; however the tissues of hermaphrodite and female lines react strongly to the lack of kinetin. This tendency subsists for a long time of culture.

\section{REFERENCES}

Astmon D., E. Galun, 1962, Ann. Bot. 26: 137-146.

Galun E., 1959, Physiol. Plant. 12: 48-61.

Galun E., S. Izhar, D. Astmon, 1965, Plant, Physiol. 40: 321-326.

Galun E., Y. Jung, A. Lang, 1962, Nature 194: 596-598.

Galun E., Y. Jung, A. Lang, 1963, Developmental Biology 6: 370-387.

Kubicki B., 1965, Genetica Pol. 6 (1-2): 153-176.

Linsmaier E. M., F. Skoog, 1965, Physiol. Plant. 18: 100-127.

Murashige T., F. Skoog, 1962, Physiol. Plant. 15: 473-497.

Preira A., S., R., 1968, Planta (Berl.) 80: 349-358.

Rennert A., 1968, Zesz. Nauk. UŁ, Ser. II, Biol. z. 30: 69-80.

Rennert A., M. Gubański, 1962, Acta Soc. Bot. Pol. 31: 545-552. 
Indukcja $i$ wzrost tkanki kalusowej z fragmentów lodyg $i$ pqków kwiatowych roślin różnych typów plciowych Cucumis sativus L. w hodowli in vitro

\section{Streszczenie}

Szczytowe fragmenty łodyg oraz pąki kwiatowe różnych typów płciowych ogórka hodowano w warunkach sterylnych na pożywce Linsmaier i Skooga z dodatkiem wyciągu pierzgi oraz 2 mg IAA i $2.2 \mathrm{mg}$ kinetyny na litr. Kalusy wytworzone na fragmentach łodyg oraz pąki kwiatowe, w całości lub po przedzieleniu na połowy, przenoszono na świeże podłoża zawierające IAA i kinetynę w różnych kombinacjach.

Przy braku auksyny w podłożu lub przy niskim jej stężeniu ( $2 \mathrm{mg} / \mathrm{l})$, pąki linii męskiej i jednopiennej ginęły, natomiast pąki linii żeńskiej i hermafrodytycznej wykazywały pewien stopień wzrostu nie tworząc kalusa. Indukcję kalusa u pąków wszystkich linii obserwowano przy wysokim poziomie IAA $(5 \mathrm{mg} / \mathrm{l})$ i w obecności kinetyny $(1 \mathrm{mg} / \mathrm{l})$. Sam IAA nie pobudzał wzrostu kalusa.

Wzrost tkanek kalusowych z fragmentów łodyg wymagał obecności obu regulatorów, a optymalne ich stężenia ulegały pewnym wahaniom w czasie kilku pierwszych pasaży zależnie od typu płciowego. Optymalne w badanym zakresie stężenia IAA i kinetyny, uzyskane w pasażu V wynosiły w mg na litr: dla linii jednopiennej i męskiej - 6 i 2, a dla linii hermafrodytycznej i żeńskiej 5 i 2,5 .

Na podstawie przeprowadzonych doświadczeń można stwierdzić, że tkanki linii męskiej i jednopiennej są bardziej wrażliwe na niedobór IAA, podczas gdy tkanki linii hermafrodytycznej i żeńskiej silniej reagują na brak kinetyny. Tendencja ta utrzymuje się przez dłuższy czas trwania hodowli. 